\title{
From Vienna to Vienna: European Philosophy of Science
}

\section{Adam Tamas Tuboly}

\section{Science \& Education}

Contributions from History, Philosophy and Sociology of Science and Mathematics

ISSN 0926-7220

Volume 25

Combined 7-8

Sci \& Educ (2016) 25:939-942

DOI 10.1007/s11191-016-9850-6
CODEN SEEDEQ

ISSW 0926-7210

Volume 25 - Numbers 7-8 • September-October 2016

\section{Seience \& Edueation}

\section{Contributions from History, Philosophy and Sociology of Seience and Education}

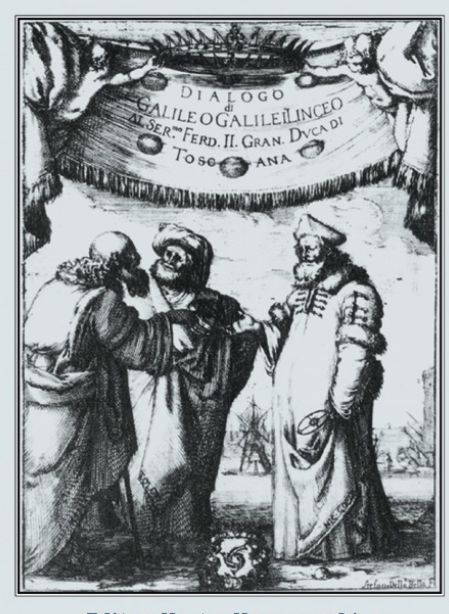

Editor: Kostas Kampourakis

Din Springer 
Your article is protected by copyright and all rights are held exclusively by Springer Science +Business Media Dordrecht. This e-offprint is for personal use only and shall not be selfarchived in electronic repositories. If you wish to self-archive your article, please use the accepted manuscript version for posting on your own website. You may further deposit the accepted manuscript version in any repository, provided it is only made publicly available 12 months after official publication or later and provided acknowledgement is given to the original source of publication and a link is inserted to the published article on Springer's website. The link must be accompanied by the following text: "The final publication is available at link.springer.com". 


\title{
From Vienna to Vienna: European Philosophy of Science
}

\author{
Maria Carla Galavotti, Elisabeth Nemeth, and Friedrich Stadler \\ (eds) (2014) European Philosophy of Science: Philosophy of Science \\ in Europe and the Viennese Heritage (Vienna Circle Institute \\ Yearbook, Volume 17) Springer, ISBN: 9783319018980, 409 pp, \\ \$179.00 (hardback)
}

\author{
Adam Tamas Tuboly ${ }^{1}$ \\ Published online: 19 August 2016 \\ (C) Springer Science+Business Media Dordrecht 2016
}

Though the English-speaking world produced some important works in the nineteenth and early twentieth century (note, e.g., John Stuart Mill, William Whewell, and C. S. Peirce), modern history and philosophy of science were born in continental Europe, in countries such as France, Germany, and the Austro-Hungarian Monarchy, and later in Austria. The reviewed work, European Philosophy of Science-Philosophy of Science in Europe and the Viennese Heritage, edited by Maria Carla Galavotti, Elisabeth Nemeth, and Friedrich Stadler, which is Volume 17 of the Vienna Circle Institute Yearbook, is just about European philosophy of science.

Two themes dominate the volume: (1) the aforementioned European philosophy of science and (2) the celebration of the twentieth anniversary of the Vienna Circle Institute. The Vienna Circle Institute plays an important role also in the context of (1). After most members of the Vienna Circle emigrated from Austria, only Victor Kraft and Béla Juhos stayed in Vienna to continue the earlier researches done by Schlick, Carnap, and others. Actually during the late 1940s, there was an attempt by Arthur Pap, Paul Feyerabend, Herbert Feigl, Elisabeth Anscombe and others to revive the spirit of the Circle (this is called the "Third Vienna Circle"), but their efforts were unsuccessful. Later, Wolfgang Stegmüller made important contributions according to the earlier Viennese lines. Nonetheless, European, especially Austrian history and philosophy of science were always quite special, both in its context and its scope.

The Vienna Circle Institute (founded by Friedrich Stadler in 1991) aims to promote, uphold, investigate, and revive the works done by logical empiricists and their associates in the twentieth century, especially by the Vienna Circle. Thanks to the efforts of Stadler and many prominent scholars linked to the Institute from both sides of the Atlantic Ocean, the renewed interested (going back at least to Rudolf Haller in the 1980s) in logical empiricism developed into a detailed and sharp research program and/or paradigm. Though much work

Adam Tamas Tuboly

tuboly.adam@btk.mta.hu

1 Institute of Philosophy, Hungarian Academy of Sciences, Budapest, Hungary 
was done already, there is still much to do-especially in the archives and regarding the general historical episodes about successes and failures in the past.

The present volume is a neat contribution to these issues. It contains 20 chapters based on papers presented at the 2011 conference in Vienna under the same title, with the support of the European Science Foundation. The first chapter is Friedrich Stadler's detailed summary of the last twenty years of the Institute's public work. Though Stadler might be a bit too laconic for someone without the required background knowledge about the many logical empiricists, it is a quite comprehensive material about the fascinating work that was done in Vienna. It might also be important for anyone working in logical empiricism, as a reference point about where to look for materials produced in the last twenty years.

The other chapters could be divided into three general categories: (1) works about logical empiricism, (2) works in the context of and related to European philosophy, and (3) general philosophy of science articles. They are devoted to such issues as history and/or philosophy of science (Cristina Chimisso about Bachelard and philosophy of chemistry, Claude Debru about dreams, and the scientific controversies and issues around sleep studies); probabilities and related notions (Maria Carla Galavotti about probabilistic epistemology, Michael Esfeld about epistemological and ontological reduction, Wlodek Rabinowicz and Lina Eriksson about betting interpretation and the notion of degrees of belief, Jeanne Peijnenburg and David Atkinson about probabilities of probabilities and regress); mathematics (Ladislav Kvasz about mathematical knowledge based on experience, Pablo Lorenzano about mathematical models and tools in biology); Philosophy of Science in Poland (Jan Woleński about Kazimierz Twardowski); Physical Sciences (John D. Norton about infinite idealizations in statistical physics); Social Sciences (Herlinde Pauer-Studer about Hans Kelsen's legal positivism), whereas Jan Faye considers the prospect of unity of science, with special attention to the logical empiricist version.

Six chapters are devoted to the history and philosophy of logical empiricism. Thomas Uebel considers Carnap's Aufbau and the question of physicalism. Though he already took into account Carnap's major work in his earlier works on Neurath, now he goes deeper about the thesis that the psychological concepts and physical concepts are "mutually reducible" to each other in the Aufbau. Uebel distinguishes a strong and a weak version of what he calls the "intertranslatability thesis" (p. 46), discusses their places in the Aufbau, and argues that Carnap took the reduction of the autopsychological to the physical to be problematic already in the Aufbau, and hence concludes that "it is not the case that [...] Carnap could have been even only a quasi-physicalist if he had wanted to" (p. 55). (It should be noted that Uebel continued his investigations into Carnap, physicalism and the Aufbau in Christian Damböck's (ed.) Influences on the Aufbau, Springer, 2016, pp. 51-75).

The second chapter concerning logical empiricism is by Richard Creath about Carnap's early arguments against metaphysics and their contemporary relevance. Creath's short piece is not a typical academic paper, sounding rather like a manifesto, or a short situation report. Nonetheless, it has a rightful place in the volume. Creath produced some clarifying remarks about the scope and context of Carnap's metaphysics critique (mainly from his Pseudoproblems in Philosophy) and discussed those presuppositions (like the structure of the Aufbau, the nature of evidence, the patterns of scientific inference, and the extent of our knowledge) that are usually ignored and thus cause some misunderstanding. The most important part of the chapter is, however, where Creath claims that "we still have a superfluity of horoscope readers, religious and ethnic bigots, evolution and climate change deniers, radio talk show hosts, and, in the USA, candidates for high public office" (p. 74). It would be important to see the various parallels between the late 1920s/early 1930s and 
our contemporary situation. (Many fear a similar right-wing political development, with some dogmatically religious underpinnings.)

Günther Sandner's chapter about Otto Neurath is based on hitherto unknown archival materials. Its subject is Neurath's early development as a socially and politically engaged student, citizen, and scholar. Sandner explores those figures that had a decisive effect on Neurath's thinking, especially on the relation of science and politics. Though the chapter touches upon important questions (such as the meaning of "Marxism," "politics," "apolitical," "social and political engagement" in the original context of Neurath's time), the whole seems to be a bit of a research summary. Hence, one is tempted to say, the reader is eager to read also in English Sandner's outstanding political bibliography of Neurath (published already in German).

Two chapters are devoted to logical empiricists' philosophy of science. Firstly, Thomasz Placek gives a succinct analysis of the notion of (in)determinism used in the Vienna Circle. He focuses on Schlick and especially on the mature Philipp Frank and shows their various approaches to handle the supposedly "tautological" character of the thesis of (in)determinism. The most laconic but promising part of his chapter is where he tries to make explicit the possible historical lines (or the lack of them) from the Vienna Circle to the second half of the twentieth century (Arthur Prior, Saul Kripke, and others).

The other chapter, written by Matthias Neuber, is aimed to show that "it has been largely ignored by the historians of logical empiricism that there indeed existed a realist faction within the logical empiricist movement" (p. 249, emphasis in the original). Neuber dismisses the ideas of Reichenbach and Feigl, since even though they are considered to be scientific realists (contrary to Carnap), their "realism is dependent on the pragmatic dimension of adopting certain language forms (or linguistic frameworks)" (p. 259). Though Neuber does not say that explicitly in the chapter, in the mentioned sense Carnap could be viewed also as a realist. What Neuber is looking for is a sense of realism that aims for a language- and mind-independent reality in the fullest sense of ontology. His conclusion is that Eino Kaila maintained the closest view to such realism-unfortunately, the chapter ends where it could bring in new perspectives into the debates, and the reader is referred to other papers of the author.

The last chapter to be mentioned about logical empiricism is Eckehart Köhler's piece on Carnap's and Gödel's philosophy of mathematics. The chapter is not just much longer than the aforementioned ones, but touches on so many problems and notions that it makes it quite hard to follow at once. Nevertheless, it is an outstanding work on Carnap and his philosophical oeuvre from his Syntax to his last papers, contrasted with Gödel's recently published remarks about Carnap's Syntax program. Köhler discusses conventions, syntax, semantics, decisions, and intuitions-one of the most important features of his chapter is the discussion of Carnap's late acceptance of intuitions as important tools in scientific activity. However, unfortunately in the Gödel parts of the article Köhler did not compare his views with that of André Carus and Stewe Awodey, who published important papers on Gödel's critique of Carnap.

Finally, referring back to the title of the collection and the introduction of the present review, Gereon Wolters brings the idea of European philosophy of science to the foreground and he is not optimistic. He describes the situations in a way that shows that European philosophy of science is ruled by Anglophone dominance. The non-native English speakers are in quite an unfavorable situation for various reasons (pp. 277-289) this affects not just their own careers in Europe both also in their own country (where the most important standard seems to be visibility in the Anglophone circles), but it has a devastating impact on European philosophy of science too. At the end of his chapter (pp. 
289-291), Wolters offers six possible paths, tools, and advices to improve the chances of a genuine European philosophy of science; unfortunately, his ideas aims to bring equality to the field by making non-native English speakers better English speakers and not the other way around, or otherwise.

The reviewer would like to call attention to two chapters from the "General Part" of the volume (which also contains the written version of the "18th Vienna Circle Lecture" held by Dagfinn Føllesdal about "Husserl and Gödel on Mathematical Objects and our Access to them"). The first one is Veronika Hofer and Michael Stöltzner's "Vienna Circle Historiographies," in which they summarize and, more importantly, catalog both the logical empiricists' self-historiographies and the later philosophical and historical works done on logical empiricism, usually connected to the Vienna Circle Institute. The other chapter is Massimo Ferrari's review essay on recent works on Moritz Schlick. He summarizes and evaluates Volume 2 of Schlick-Studien and Volumes 3 and 5 of Schlickiana. Both of them are more than interesting and important for anyone interested in the general lines of recent work on logical empiricism.

Summing up, the 17th volume of the Vienna Circle Institute Yearbook contains many insightful chapters, which might be rightfully taken as reference points for further research for anyone working inside and/or outside the European philosophy of science scene.

\section{Compliance with ethical standards}

Conflict of interest The author declares that there is no conflict of interest. 